November 2007

\title{
The Order of Genocide : The Dynamics of Genocide in Rwanda
}

Scott Straus

Follow this and additional works at: https://digitalcommons.usf.edu/gsp

\section{Recommended Citation}

Straus, Scott (2007) "The Order of Genocide : The Dynamics of Genocide in Rwanda," Genocide Studies and Prevention: An International Journal: Vol. 2: Iss. 3: Article 6.

Available at: https://digitalcommons.usf.edu/gsp/vol2/iss3/6

This Articles is brought to you for free and open access by the Open Access Journals at Digital Commons @ University of South Florida. It has been accepted for inclusion in Genocide Studies and Prevention: An International Journal by an authorized editor of Digital Commons @ University of South Florida. For more information, please contact digitalcommons@usf.edu. 


\title{
The Order of Genocide: The Dynamics of Genocide in Rwanda
}

\author{
Scott Straus \\ Department of Political Science, University of Wisconsin, Madison
}

\section{Introduction}

To begin, I'd like to describe the origins of the research project that ultimately became The Order of Genocide. I first traveled to Rwanda as a journalist in the mid-1990s, and, during my travels there and in what was then Zaire, I became deeply interested in the dynamics that ultimately led to the 1994 genocide. From my perspective as a journalist traveling in the region, the genocide was an absolutely seminal event, but one that was poorly understood. Eventually I returned to the United States and began a $\mathrm{PhD}$ program in political science at the University of California, Berkeley, where I began to study the origins of genocide and mass violence, African politics, and the history of the Great Lakes region. The Order of Genocide is based on my $\mathrm{PhD}$ dissertation.

Three related questions drove my initial inquiry. First, what explains the ability of Rwandan elites to mobilize a large number of citizens effectively and quickly during the genocide? The literature on African states consistently indicates that governments are relatively weak, especially outside the capital. Yet in Rwanda state authorities successfully solicited the participation of hundreds of thousands of citizens in an extermination campaign. Second, what explains the participation of ordinary civilians in the genocide? When I began to research Rwanda in the late 1990s there was much speculation but little by way of satisfactory answers to this question. Yet given the scale of participation, understanding the dynamics and conditions driving individuals seemed crucial. Third, why did the elites choose the strategy they did? The literature on Rwanda was clear that governing, military, and party officials fomented mass violence; the genocide was not a spontaneous eruption of hatred. Moreover, an instrumentalist consensus dominated the literature: elites were said to have deliberately advocated violence to protect and promote their interests. But instrumentalist hypotheses go only so far; they do not say why elites chose a strategy of genocide over alternatives.

As I considered these questions, a separate set of concerns began to occupy me. In particular, I became concerned about the gap in detailed evidence about the genocide. Most existing empirical information was anecdotal or focused on the top (such as discussions of the history of ethnicity or examinations of national-level propaganda before and during the genocide). There was relatively little empirical information about the dynamics of the genocide in rural areas, where the absolute majority of violence occurred. ${ }^{1}$ In short, the situation I found as I began to research Rwanda was that a number of key questions remained unanswered and there was little systematically collected evidence that could be used to evaluate different hypotheses. To compensate, I sought to create a research design that would allow me to generate new empirical information and to evaluate different arguments.

As many who read this journal know, generating evidence about the dynamics of genocide presents specific problems. Three in particular stood out for me as I started 
my research. First, in the aftermath of genocide and the wars in the Congo, trauma and fear were widespread. Second, narratives were highly politicized, and individuals across the political spectrum presented highly interested and stylized accounts. Third, because the topic was the subject of criminal prosecutions, the research questions had inevitable legal and political implications and were also of concern to institutional oversight boards, with whose regulations I, like many US-based researchers, had to comply.

\section{Research Design}

Nonetheless, I designed a field research program that consisted of three main stages. Because my questions focused on the dynamics of violence, I decided to focus primarily, though not exclusively, on those who took part in the killing. The first and main research phase was a nationwide survey of imprisoned perpetrators. For the survey, I used a stratified random sampling method to select and interview sentenced perpetrators who had pleaded guilty in Rwanda's domestic courts. The central research instrument was a semi-structured questionnaire, which I designed to evaluate competing hypotheses about the dynamics of violence and participation in it. In total, using this method, I interviewed 210 prisoners in fifteen central prisons across Rwanda.

The second research phase involved comparing the dynamics of genocidal violence in five Rwandan communes (the main local unit of administration in 1994). During my first research phase, I discovered that the patterns of mobilization that led to the onset of genocide varied from commune to commune (more on this below). In addition, there was one commune under government control where genocide did not occur. For this second research phase, therefore, I selected four communes that exhibited variation in how genocide began as well as the one commune under government control, Giti, where genocide did not take place. I then studied the dynamics of violence in each commune in depth through interviews with perpetrators, survivors, current and former government officials, and non-participating Hutus.

The third stage of research entailed return trips to prisons. During the first two phases, one clear pattern had emerged: in most communities, a nucleus of core perpetrators was central to how the violence unfolded. While some of those individuals fell into my random sample in the first phase, most respondents were lower-level perpetrators. Thus, for the third research phase, I selected particular individuals to interview, ranging from top communal authorities to young men who were particularly active killers in the genocide. I interviewed about nineteen individuals using this method. In addition to this field research, I also collected as much information as I could from secondary sources, such as court documents, human-rights reports, government studies, journalist accounts, and scholarship.

\section{Principal Findings}

One important finding from my research is that there was significant regional and local variation in when and how the violence started. Immediately after President Juvénal Habyarimana's assassination-the trigger for the genocide-national hardliners seized control of the Rwandan state and called for the killing of all Tutsis and prominent Hutu political opponents. However, that call did not translate into actual violence at the same time in all regions. In some areas, genocidal violence began within days of the president's assassination; in other areas, however, it did not begin 
until four or five days after his death, while in still others the violence took two weeks or more to get started. In many areas, Hutu leaders and ordinary civilians initially responded negatively to calls from the central government to kill Tutsis. By and large, the areas that initially resisted efforts to start the violence were those where the domestic Hutu political opposition had the most support. Genocidal violence ultimately began, and succeeded, in those areas, but not before an important delay and not without a power struggle among Hutus.

In terms of how violence began, significant variation existed among local areas. In some places, local administration officials clearly started and directed the killing. In other areas, however, the push came from military officers. In still others, political party leaders and militia took charge. In some areas, local elites outside the official administrative hierarchies mobilized to assume control. And in many areas some combination of these occurred: soldiers worked with local officials or militia and the rural elite worked with political party officials.

The point to emphasize is that, even though the genocidal outcome was similar across Rwanda, how and when the violence started varied considerably. Not all Hutus responded in the same way to the call to commit genocide. That finding is inconsistent with some common hypotheses about the genocide, particularly the idea that the decision to take part in the genocide stemmed from a widespread racist culture and indoctrination; it is also inconsistent with the claim that the genocide was seamlessly and hierarchically orchestrated, with local officials and peasants blindly following orders. In fact, the spread of genocidal violence looked more dynamic, like a cascade of tipping points, rather than being meticulously prepared and implemented.

I collected demographic information from perpetrators, including age, occupation, number of children, literacy, and years of education. The general finding is that the perpetrator profile, judging from my sample, was quite similar to that of the adult male Hutu population in Rwanda at the time of the genocide. In other words, on the whole, the perpetrator population was not comparatively younger, more unemployed, or better educated. Rather, the perpetrators were average Rwandan men.

With respect to ethnicity, I found little evidence of widespread interpersonal ethnic hatred. On a series of indicators-interethnic personal relations, attitudes toward ethnic intermarriage, and family connections to Tutsis through intermarriage- the survey yielded consistent evidence among respondents of positive pre-genocide ethnic interaction. That said, many respondents spoke in categorical terms about "Hutus" and "Tutsis," in particular when discussing the very tense period after Habyarimana's assassination. Some respondents also repeated elements of the genocidal regime's propaganda, such as the idea that the rebels killed Hutu children and disemboweled pregnant women. On the other hand, certain commonly cited propaganda elements had limited resonance. For example, less than $10 \%$ of respondents had heard of-let alone respected-the infamous "Hutu Ten Commandments."

To investigate the issue of motivation, I asked respondents direct and indirect questions about how and why they chose to participate in the genocide. As expected, respondents expressed a range of motivations, from looting to joining attacks to avoid suspicion that they were hiding Tutsis in their homes. However, two main types of motivations emerged from these interviews. The first was some form of intra-Hutu intimidation. Many respondents said that once the violence started in their communities, they faced strong pressure from other Hutus to participate and feared negative consequences for themselves and their families if they refused. The second most common motivation was war-related: respondents said that, in the aftermath of 
Habyarimana's death, they feared that the Rwandan Patriotic Front (RPF) was invading Rwanda and was killing Hutus.

This discussion of my findings is very brief. Considerably more detail, evaluation, and triangulation of the findings, as well as historical analysis of prior periods of violence, can all be found in the book.

\section{The Argument}

In The Order of Genocide, I conclude that three main factors drove the genocide in Rwanda. First, war: I argue that the context of war was critical for the outcome. War provided the essential rationale for mass killing: security. The logic of Rwanda's genocide was predicated on eliminating a threat, on self-protection, and on re-establishing order. Moreover, the war that took place during the genocide was intense and defensive, and thus it created a climate of acute uncertainty and insecurity, sometimes a feeling of panic. That context was critical in motivating some individuals to foment violence; it was also a key reason that individuals who gravitated toward extreme measures gained the upper hand wherever they were.

The assassination of Rwanda's president was part of this dynamic. The assassination ruptured Rwanda's political order and thereby created a temporary gap in authority. The president's death independently caused anger, leading to calls for violent revenge; the assassination augmented the anxiety, fear, and confusion of the war; and the rupture in political order also set the stage for local power struggles. This last factor is particularly important. After the president's death, Hutu hardliners succeeded in gaining control of the state and urged war against the Tutsi "enemy." That idea-war against the Tutisis-then became the terms around which local actors asserted power and authority in their communities. The hardliners and those who adhered to the program of genocide ultimately won the upper hand in almost all areas not yet lost to the rebels. But such would not likely have happened outside a context of war, including the president's assassination.

Given the importance of war and of the president's assassination, as well as my findings about how the genocide unfolded at the local level, I conclude that a dynamic of escalation was a critical factor in the genocide. That, in turn, leads me to argue that while the genocide was organized, systematic, and ultimately promoted by the hardliners who took control of the state after the president's assassination, the genocide-meaning here the countrywide extermination of the Tutsi populationwas not necessarily meticulously planned in advance, as is often claimed. To be clear, I argue that the Hutu hardliners who controlled the state are responsible for the actions they took and, ultimately, for the genocide; however, the dynamics that led them to foment mass violence, and to succeed in doing so, were in part situational and, in particular, had to do with the course of the war, including the president's assassination.

Second, Rwandan state institutions are critical to understanding why genocide happened and the participatory character of the violence. The Rwandan state matters for a number of reasons. First, the state has unusual depth and resonance at the local level in Rwanda, which meant that, by controlling the state, the hardliners had the capacity to enforce their decisions countrywide. Second, control of the state allowed the hardliners to associate killing Tutsis with authority, thus equating violence with de facto policy. Third, Rwanda has a long history of obligatory labor, and expectations derived from that history contributed to large-scale civilian mobilization during the genocide. The potency of the Rwandan state cannot be taken for granted, 
especially because most African states are weak-particularly in rural areas. Thus, in addition to demonstrating the importance of the state to the outcome of genocide, I also explain in the book why Rwanda's state is so effective at civilian mobilization. Here I emphasize Rwandan political history, dating to the precolonial period, as well as the country's dense geography.

Therein lies a tension. In The Order of Genocide I make the case that insecurity, uncertainty, anger, and fear related to war and to the president's assassination drove the promulgation and spread of violence. However, once coalitions of actors emerged to win effective control in their communities, they drew on the power of Rwanda's local state and the resonance of authority to unleash violence quickly and effectively. The nature of Rwanda's institutions and geography also limited exit options, which both drove high rates of Hutu participation and limited escape opportunities for Tutsis. The result was a very rapid killing campaign.

Third, ethnicity mattered, but in surprising ways. Overall, I found that ethnic prejudice, ethnic antipathy, manipulation by racist propaganda, and nationalist commitments were not the primary drivers. However, the logic of extermination in Rwanda depended on the idea that Tutsis are of a piece. The genocidal mandate from the hardliners was to equate "enemy" with "Tutsi" and to declare that Rwanda's "enemies" had to be eliminated. I argue in the book that the mechanism that allowed this process to happen is collective ethnic categorization. In case after case, when justifying killing civilians, perpetrators substituted the category "Tutsi" for the individuals they were attacking.

The hardliners did not create this category from thin air. Ethnic and racial categorization has a deep and significant political history, dating, in particular, to the early colonial period and extending in periodic but pronounced ways into the first two postcolonial republics. In short, the ethnic/racial categories were ingrained, even if ethnic hatred was not, and those categories ultimately were essential to the character of violence-to the fact that violence in Rwanda became genocide.

What caused a shift from an awareness of ethnic categories to collective categorization and violence? I argue the principal mechanisms had to do with uncertainty, fear, social pressure, and opportunity. In the aggregate, Hutus participated in genocide because they wanted to protect themselves during a war and a period of intense uncertainty; because they felt that complying with those who told them to kill would be less costly than not complying; and because they opportunistically used the period of confusion and violence to obtain power and property. These dynamics, I argue, are inseparable from the specific context of war and from the nature of Rwandan state institutions and geography.

\section{Implications for Post-Genocide Rwanda}

Like the presentation of my findings, my argument here is truncated.

In closing, I would like to discuss briefly-again, more detail is in the book-the implications of my findings and argument for post-genocide Rwanda.

Rwanda's RPF-dominated post-genocide government has favored strong control over public political discourse and maintained a strong military emphasis. These policies are based, at least in part, on an interpretation of mass participation in the genocide that tends to see the genocide as an undifferentiated event and the main cause of participation as mass beliefs and mass racist indoctrination. This interpretation essentially posits a persistent post-genocide threat, because the Hutu population is considered to be either genocidal or brainwashed and thus prone 
to becoming genocidal. The logical response to such an ongoing threat is strong coercive control over the potentially dangerous population.

However, there is substantial risk that a strong security outlook, even though it will keep the peace in the short term, will alienate large portions of the population and sow the seeds of instability in the long term. Here the evidence I collected could contribute to rethinking policy. First, the evidence does not support collective blame of the Hutu population. Not all Hutus were génocidaires, and not all perpetrators participated to the same degree. Second, the genocide was not perpetrated in a seamless, "machine"-like manner. Rather, the violence was the outcome of local-level struggles for dominance, and many initially resisted or tried to avoid becoming involved in it. Third, the evidence suggests that while ethnic categories were an important background condition for the genocide, neither interpersonal ethnic enmity nor a deeply imbibed racist culture was the wellspring of most individuals' participation in the violence. Rather, specific conditions in Rwanda triggered the saliency of ethnic categories and enabled a dynamic of violence to take hold. Thus, in considerations of how prone Rwanda is to future violence, the stress should fall on those situational factors that sowed the seeds of insecurity and destabilization that allowed a dynamic of violence to take root.

All this indicates that some key conditions that facilitated the genocide in the first place are no longer present. By extension, the prospects for post-genocide confidence among social groups may be greater than many Rwandan and outside observers fear. Nothing about social reconstruction after mass violence is easy, but my evidence shows that Rwanda is not, and was not, a nation of people predisposed to violence.

\section{Acknowledgments}

I would like to express my sincere thanks to Samuel Totten for publishing this book forum and to the three commentators.

\section{Note}

1. An exception was Alison Des Forges' impressive human-rights documentation: Alison Des Forges, Leave None to Tell the Story: Genocide in Rwanda (New York: Human Rights Watch, 1999). 